\title{
TEMPORAL EVOLUTION OF GREENHOUSE GAS EMISSIONS IN EUROPEAN UNION (EU-28): A PERSPECTIVE ON ROMANIA
}

\author{
Mihaela Iordache ${ }^{1}$, Ramona Zgavarogea ${ }^{1^{*}}$, Andreea Maria Iordache ${ }^{1}$, Marius \\ Constantinescu ${ }^{1}$, Felicia Bucura ${ }^{1}$, Roxana Elena Ionete ${ }^{1}$, Remus Grigorescu ${ }^{2}$, \\ Constantin Nechita ${ }^{3 *}$
}

\author{
${ }^{I}$ National Research and Development Institute for Cryogenics and Isotopic Technologies - ICSI Rm. \\ Valcea, 4 Uzinei Street, P.O. Box Râureni 7, 240050, Rm. Vâlcea, Romania \\ ${ }^{2}$ Constantin Brancoveanu University, Bulevardul Nicolae Bălcescu 39, 240177, Râmnicu Vâlcea, \\ Romania \\ ${ }^{3}$ National Research and Development Institute for Forestry "Marin Drăcea" Calea Bucovinei, 73 bis, \\ 725100, Câmpulung Moldovenesc, Romania
}

\begin{abstract}
:
The European mitigation strategy for combatting climate change requires up-to-date knowledge about the environmental effects of greenhouse gas (GHG) emissions at the national scale. As a strong response to the consequences of climate change, the European Union has imposed on the member states an obligation to achieve the goals set out in the climate and energy package, which were aimed at reducing emissions. Therefore, underlying the trends of GHG emissions is essential when establishing climate change mitigation measures. This study identify the structure and dynamics of the GHG emissions of the six sectors of the European economies, over 27 years, and reveal the significance, direction, rate, and drivers of the observed trends using the method of modifying the absolute mean. The results indicate a decrease in the GHG emissions in the EU-28 by an average of $1 \%$ annually, which can be explained by a mixt factors, such as resize of the industry, improved energy efficiency, the growing share of renewables and less use of carbon fuels. Moreover, through the environmental policies adopted in the last decade, was observed that the GHG emissions level in 2017 had declined by approximately $25 \%$ in comparison with the reference (1990) and by approximately $17 \%$ by 2005 . From the 28 EU countries (EU-28), Romania produced $4.2 \%$ of the total EU-28 GHG emissions in 1999, which decreased to $2.7 \%$ in 2005 and reaching $2.3 \%$ in 2017. Romania contributed to $14 \%$ of the average annual decrease in emissions. This evidence highlights the additional support for further reduction beyond that required for climate change mitigation.
\end{abstract}

\section{Article info:}

Received 14 February 2021

Received in revised form

26 March 2021

Accepted 16 April2021

Available online 8 November 2021

Keywords:

climate change; $\mathrm{CO}_{2}$, environmental policies; greenhouse gas emissions; sustainable development

"Corresponding authors: Constantin Nechita, E-mail: ncincds@gmail.com and Ramona Zgavarogea, E-mail: ramona.zgavarogea@icsi.ro 
How to cite: Iordache, M., Zgavarogea, R., Iordache, A. M., Constantinescu, M., Bucura, F., Ionete, R. E., Grigorescu, R., Nechita, C., (2021). Temporal evolution of greenhouse gas emissions in European Union (EU28): A perspective on Romania. Smart Energy and Sustainable Environment, 24(2), 43-58, https://doi.org/10.46390/j.smensuen.24221.438

\section{INTRODUCTION}

Humanity faces a significant threat, the climate change. People are exerting an increasing influence on the Earth's climate and temperature by burning fossil fuels, clearing tropical forests and raising animals. These activities generate vast quantities of greenhouse gases (GHG), which add to those already naturally present in the atmosphere, thus contributing to the greenhouse effect and global warming (Rive and Fuglestvedt, 2008). Anthropogenic activities contribute to GHG emissions, and today, their impact on global warming is increasing (Torres and Pinho, 2011), since human-induced warming reached approximately $1^{\circ} \mathrm{C}$ above preindustrial levels in 2017 , rising at $\sim 0.2^{\circ} \mathrm{C}$ per decade (Allen et al., 2018). High temperatures have unprecedented consequences across the globe. They cause glaciers to melt and sea level to rise. They have brought floods or droughts to regions that were previously immune to such extreme phenomena. These abnormal weather conditions have an increasing impact on economies, the environment, health and daily life (Krausmann et al., 2020).

GHG emissions allow the penetration of solar energy but prevent the release of heat from the atmosphere. A significant amount of anthropogenic greenhouse gas is represented by the carbon dioxide $\left(\mathrm{CO}_{2}\right)$, which contributes approximately $72 \%$ of the total emissions. Nevertheless, other gases, such as methane $\left(\mathrm{CH}_{4}\right)$, nitrous oxide $\left(\mathrm{N}_{2} \mathrm{O}\right)$ and fluorinated gases, also accumulate substantial shares (19\%, 6\% and 3\%, respectively) (Olivier et al., 2017). $\mathrm{CO}_{2}$ is the greenhouse gas most often generated by human activities, its concentration in the atmosphere is currently $40 \%$ higher than in the preindustrial period. Currently, the atmospheric concentration of carbon dioxide appears to be at the highest level in the last 800,000 years (WMO, 2016).

Europe is already highly urbanized, with $74 \%$ of the population living in urban areas, with an expected increase to $80 \%$ by 2050 . Furthermore, globally, cities are responsible for over $78 \%$ of global energy consumption and over $60 \%$ of GHGs. They are also responsible for $85 \%$ of the gross domestic product and are therefore of critical importance to addressing climate change and sustainability (Harris et al., 2020). The solid waste generated in municipalities encompasses heterogeneous and homogeneous residues from urban and suburban regions. The organic components in waste dumps and landfills produce gases during anaerobic decomposition that comprise approximately $60 \% \mathrm{CH}_{4}$ and $40 \% \mathrm{CO}_{2}$, along with other trace gases (Ramachandra et al., 2018).

The larger-scale utilization of conventional fossil fuels (i.e., natural gas, oil, coal) was caused by the high energy demand specific to a rapidly growing society, becoming a key source of energy since the industrial revolution. In 2011, the global $\mathrm{CO}_{2}$ emissions registered 33.4 billion tons, according to the EDGAR database (Emission Database for Global Atmospheric Research), which is almost 50\% higher than twenty years ago. Atmospheric $\mathrm{CO}_{2}$ levels have risen by more than $39 \%$ in the last century, from $280 \mathrm{ppm}$ in the preindustrial period to $400 \mathrm{ppm}$ in 2013, with an increase in global surface temperature of about $0.8^{\circ} \mathrm{C}$.

From 2015 to date, the EU-28 share of global fossil $\mathrm{CO}_{2}$ emissions per year remained constant at 9.6\%, an equivalent of 7 tons $\mathrm{CO}_{2}$ /cap/year (Crippa et al., 2019). Even so, in the absence of adequate climate change policies and measures, it is forecast that by 2030, the GHG emissions will increase by up to $90 \%$ from 2000 levels, and the concentrations of $\mathrm{CO}_{2^{-}}$ equivalent per year in the atmosphere will enhance to values of 600-1550 ppm (Leung et al., 2014). 
Of the total anthropogenic pollutants, carbon dioxide emissions remain the main component of greenhouse gas emissions, of about $76 \%$. From it, around $90 \%$ is induced by combustion of fossil fuel combustion. Therefore, developing countries are trying to reduce GHG emissions without slowing economic growth, which means that investments in renewable energy supply and energy efficiency, foreseen as primary drivers of a sustainable energy development, should increase (Shen and Sun, 2016; Song et al., 2018; Zheng et al., 2019; Oka, Mizutani and Ashina, 2020).

The paper aims at a common and comparable analysis of GHG emissions for the 28 member states of the European Union, by sectors and chemical structure. The comparative assessment of GHG emission time-series data provide information about sector - and country specific dynamic performances towards fulfilling the commitment to the Kyoto Protocol.

Three main aspects were foreseen in this study: (i) evolution of the GHG emissions during 1990-2017, (ii) dynamics of the chemical composition of GHGs emissions and, (iii) trend of GHG emissions by economic sector.

\section{METHODOLOGY}

\section{Data sources}

The data used in this study were based on information provided by the European Environment Agency (EEA), the National Institute of Statistics (NIS Romania) and historical data from the National Greenhouse Gas Inventory (1990-2017). The emissions inventory included $\mathrm{CO}_{2}, \mathrm{CH}_{4}, \mathrm{~N}_{2} \mathrm{O}$, perfluorocarbons, hydrofluorocarbons, NF3 and SF6. Six sectors, namely, energy, industrial processes, agriculture, land use/land-use change and forestry, waste management and transport, were included according to the 2006 IPCC guidelines for national GHG emissions inventories.

All the 28 EU member states, at the level of 2017, are considered in the analysis, with a special emphasis on Romania. In general, member states of the European Union have similar economic and political conditions which makes comparisons between their GHG emissions more feasible and more efficient.

\section{Calculation method - Trends in GHG emissions}

The determination of a trend by the method of modifying the absolute mean implies that the following recurrence relationship determines the adjusted values:

$$
\hat{y}_{k}=y_{0}+k \cdot \bar{\Delta}, k=\overline{0, T}
$$

where $y_{0}$ is the term considered as the basis of the adjustment (for 1990 and for 1989, the value of $k$ is -1 ), and $\bar{\Delta}$ represents the absolute average change, which is calculated as a simple arithmetic mean of the absolute changes based on the chain as follows:

$$
\bar{\Delta}=\frac{\left(y_{1}-y_{0}\right)+\left(y_{2}-y_{1}\right)+\ldots+\left(y_{T-1}-y_{T-2}\right)+\left(y_{T}-y_{T-1}\right)}{T-1}=\frac{y_{T}-y_{0}}{T-1}
$$

The first and last adjusted values are equal to the first and last empirical values, respectively, as follows:

$$
\begin{aligned}
& \text { - } \text { for } k=0 \rightarrow \hat{y}_{0}=y_{0}+0 \cdot \bar{\Delta}=y_{0} \\
& \text { - } \text { for } k=T \rightarrow \hat{y}_{T}=y_{1}+(T-1) \cdot \bar{\Delta}=y_{1}+(T-1) \cdot \frac{y_{T}-y_{0}}{T-1}=y_{T}
\end{aligned}
$$


For extrapolation, we have continued the $k$ series until the last unit of time for the investigated horizon. Thus, values of $k$ were assigned to each year starting with the value 0 for 1990 and continuing in arithmetic progression in increments of 1 to the value 28, which corresponds to the year 2017.

\section{RESULTS}

Evolution of the GHG emissions during 1990-2017. In the EU-28, the greenhouse gas emissions decreased annually by $1 \%$ on average, indicating the level of 2017 , which was approximately 25\% lower than the reference level (1990), and approximately 17\% lower than that in 2005 (Fig. 1). The standards reached in 2017 exceeded the targets set by the EU 2020 Climate and Energy Package (CEP), which introduced a transparent approach to achieving a 20\% reduction in total GHG emissions compared to 1990 levels, which was equivalent to a decrease of $14 \%$ compared to 2005.
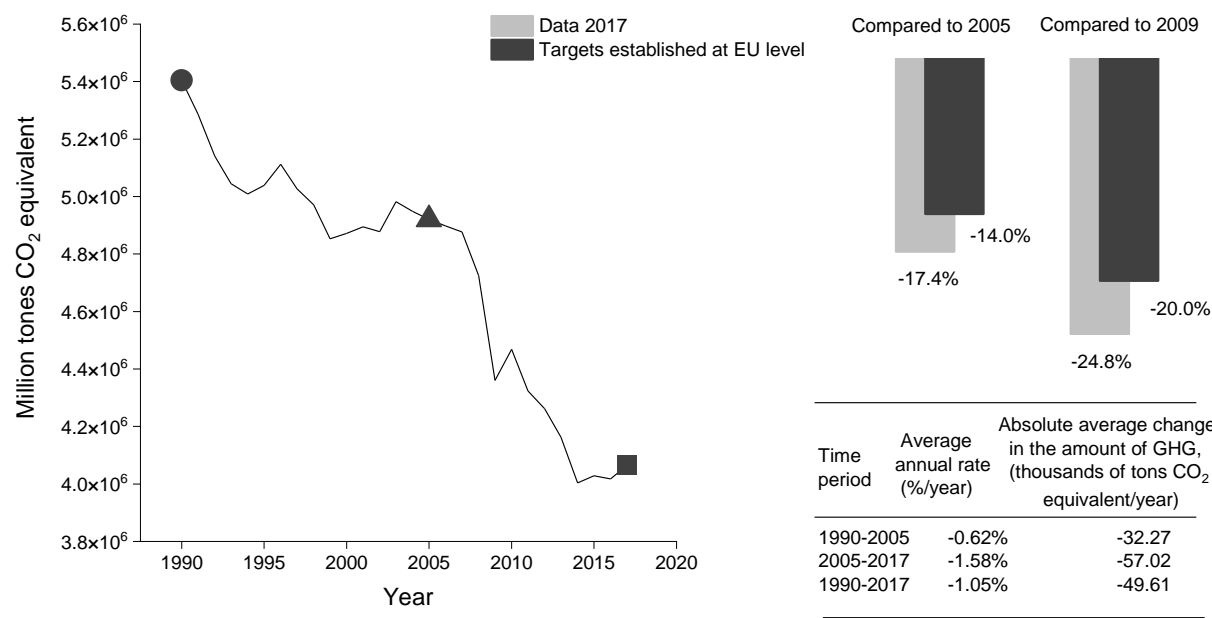

Figure 1. The dynamics of GHG emissions at EU-28 level (source: graph built by the authors based on the information provided by the European Environment Agency (EEA)

An accentuated downward trend was observed after 2005. The rate of reduction of gas emissions increased 2.5 times in the period from 2005-2017 compared to that from 19902005, which highlights the efficiency of the measures taken in the EU-28. The amount of GHG emissions decreased from $1990-2005$ by 32.3 million tons $\mathrm{CO}_{2}$-eq./year compared to the period from 2005-2017, when this quantity almost doubled, on average, from one year to another (57 million tons $\mathrm{CO}_{2}$-eq./year).

Compared to 1990, three-quarters of the EU member countries recorded reductions in emissions (21 Member States), of which 17 exceeded the 2020 target for 2017 (Table 1). In 2017, the member states with the essential reductions of greenhouse gas emissions compared to the reference year 1990 were Sweden (75.8\%), Romania (68.2\%), and Lithuania (65.0\%). In contrast, the countries with the highest GHG emissions were Cyprus (55.3\%), Portugal (29.1\%), and Spain (19.5\%). Compared to 2005, the share of the member states that registered emission reductions was of approximately 83\% (23 Member States), out of which 15 were higher than the target (14\% compared to 2005). Romania $(29.4 \%)$ is still within the first countries, with decreases above the target of 14\%, after Sweden (74.6\%), the United Kingdom (32.7\%), and Greece (30.7\%). 
Mihaela Iordache, Ramona Zgavarogea, Andreea Maria Iordache, Marius Constantinescu, Felicia Bucura, Roxana Elena Ionete, Remus Grigorescu, Constantin Nechita

Table 1. Dynamics of greenhouse gas emissions in the EU-28, for the period 1990-2017. The position of the countries, according to the countries' setting to be established through the EU 2020 CEP (million tons $\mathrm{CO} 2$ eq./year)

\begin{tabular}{|c|c|c|c|c|c|c|c|}
\hline EU-28 & 1990 & 2005 & 2017 & \multirow{2}{*}{\multicolumn{2}{|c|}{$\begin{array}{l}\begin{array}{l}\text { Target face } \\
\text { from } 1990\end{array} \\
-24.8 \% \\
\end{array}$}} & \multirow{2}{*}{\multicolumn{2}{|c|}{$\begin{array}{l}\begin{array}{l}\text { Target face } \\
\text { from } 2005\end{array} \\
-17.4 \%\end{array}$}} \\
\hline At EU-28 level & $5,404,553$ & $4,920,393$ & $4,065,089$ & & & & \\
\hline$A$ & 1 & 2 & 3 & 4 & $5^{*}$ & 6 & $7^{*}$ \\
\hline Austria & 66.682 & 81.907 & 77.355 & $16.0 \%$ & 25 & $-5.6 \%$ & 23 \\
\hline Belgium & 143.273 & 143.747 & 114.280 & $-20.2 \%$ & 17 & $-20.5 \%$ & 11 \\
\hline Bulgaria & 89.632 & 51.926 & 53.335 & $-47.6 \%$ & 5 & $2.7 \%$ & 24 \\
\hline Croatia & 25.204 & 22.245 & 20.253 & $-19.6 \%$ & 18 & $-9.0 \%$ & 21 \\
\hline Cyprus & 5.418 & 8.956 & 8.411 & $55.3 \%$ & 28 & $-6.1 \%$ & 22 \\
\hline Czech Republic & 192.167 & 140.457 & 126.540 & $-34.2 \%$ & 11 & $-9.9 \%$ & 18 \\
\hline Denmark & 74.099 & 70.021 & 50.582 & $-31.7 \%$ & 12 & $-27.8 \%$ & 5 \\
\hline Estonia & 38.942 & 16.272 & 19.087 & $-51.0 \%$ & 4 & $17.3 \%$ & 27 \\
\hline Finland & 56.361 & 45.385 & 34.956 & $-38.0 \%$ & 10 & $-23.0 \%$ & 9 \\
\hline France & 525.910 & 510.177 & 432.662 & $-17.7 \%$ & 19 & $-15.2 \%$ & 15 \\
\hline Germany & 1.219 .681 & 981.284 & 891.426 & $-26.9 \%$ & 14 & $-9.2 \%$ & 20 \\
\hline Greece & 100.993 & 132.998 & 92.212 & $-8.7 \%$ & 21 & $-30.7 \%$ & 3 \\
\hline Hungary & 91.137 & 70.008 & 58.349 & $-41.3 \%$ & 9 & $-16.7 \%$ & 14 \\
\hline Ireland & 60.185 & 75.157 & 66.741 & $10.9 \%$ & 24 & $-11.2 \%$ & 16 \\
\hline Italy & 514.462 & 552.223 & 409.329 & $-20.4 \%$ & 16 & $-25.9 \%$ & 7 \\
\hline Latvia & 16.431 & 8.203 & 9.599 & $-41.6 \%$ & 8 & $17.0 \%$ & 26 \\
\hline Lithuania & 43.152 & 19.122 & 15.121 & $-65.0 \%$ & 3 & $-20.9 \%$ & 10 \\
\hline Luxembourg & 12.881 & 12.424 & 9.892 & $-23.2 \%$ & 15 & $-20.4 \%$ & 12 \\
\hline Malta & 2.106 & 2.911 & 2.155 & $2.3 \%$ & 22 & $-26.0 \%$ & 6 \\
\hline Netherlands & 227.285 & 219.969 & 198.860 & $-12.5 \%$ & 20 & $-9.6 \%$ & 19 \\
\hline Poland & 447.159 & 356.817 & 379.935 & $-29.4 \%$ & 13 & $6.5 \%$ & 25 \\
\hline Portugal & 60.247 & 87.130 & 77.777 & $29.1 \%$ & 27 & $-10.7 \%$ & 17 \\
\hline Romania & 229.151 & 130.446 & 92.116 & $-68.2 \%$ & 2 & $-29.4 \%$ & 4 \\
\hline Slovakia & 63.661 & 45.423 & 36.732 & $-42.3 \%$ & 6 & $-19.1 \%$ & 13 \\
\hline Slovenia & 14.177 & 13.173 & 15.929 & $8.6 \%$ & 23 & $20 ., 9 \%$ & 28 \\
\hline Spain & 252.617 & 402.837 & 301.903 & $19.5 \%$ & 26 & $-25.1 \%$ & 8 \\
\hline Sweden & 36.908 & 35.137 & 8.933 & $-75.8 \%$ & 1 & $-74.6 \%$ & \\
\hline United King & 794.633 & 684.035 & 460.617 & $-42.0 \%$ & 7 & $-32.7 \%$ & 2 \\
\hline
\end{tabular}

Note: 1. The data in columns 1, 2 and 3 are taken from authors from the European Environment Agency (EEA); 2. The data in columns 4 and 6 are calculated authors as the rhythms of the relative change in 2017 compared to 1990 (col. 4) and in 2017 compared to 2005 (col. 6); 3. In columns 5 and 7 the positions of the countries are specified according to the relative change rates of columns 4 and 6

Within the most developed economies, Germany generates more than one-fifth of the amount of greenhouse gas emissions. Our analysis highlighted Germany, Great Britain, France, and Italy, which produce more than half of the quantity of GHG emissions in the European Union. The levels produced represented approximately $57 \%$ of the total in 1990 , over $55 \%$ in 2005, and approximately $54 \%$ in 2017. Although these shares remained relatively constant, the four countries, as a whole, exceeded the set target of $28 \%$ compared to 1990 , when the aim was $20 \%$, and in 2005 , when the objective was $14 \%$.

In 1990, Romania had a share of the total EU-28 GHG emissions of 4.2\%, which decreased in 2005 to $2.7 \%$ and $2.3 \%$ in 2017 . The results can be explained by a decline in industrial production in these two years and reaction to the measures taken during pre- and post-accession to the European Union. An aspect worth mentioning is the fact that Romania ranked second after Sweden (-5.1\%/year) regarding the average annual rate of decrease for 
the period from 1990-2017, with a rate of $4 \%$ per year compared to the European average, which was $1 \%$ per year. A rapid reduction was observed from 1989-2005 with a rate of approximately $5 \%$ per year and slowed down after 2005 to approximately $3 \%$ per year. As a result of the measures taken after 2005, the number of countries that recorded average annual rates above the EU average was increasing, from 5 countries before 2005 to 13 member countries after 2005 (Table 2).

Table 2. Average annual rates of the evolution of GHG emissions in the member countries of the EU

\begin{tabular}{|c|c|c|c|}
\hline $\begin{array}{c}\text { Grouping of average annual rates by member } \\
\text { countries }\end{array}$ & $\begin{array}{c}\text { Before } \\
2005\end{array}$ & After 2005 & $\begin{array}{c}\text { Analyzed time } \\
\text { horizon }\end{array}$ \\
\hline$\bullet \quad$ Growth & 9 & 5 & 7 \\
\hline$\bullet \quad$ Above the EU average & 5 & 13 & 14 \\
\hline$\bullet \quad$ Below the EU average & 14 & 10 & 7 \\
\hline Average annual rate of the EU-28 (EU average) & $-0.62 \%$ & $-1.58 \%$ & $-1.05 \%$ \\
\hline
\end{tabular}

\section{Dynamics of the chemical composition of GHGs emissions.}

According to the UNFCCC reporting guidelines, national stocks covered emissions and discharges of the following GHGs: carbon dioxide $\left(\mathrm{CO}_{2}\right)$, including indirect $\mathrm{CO}_{2}$; methane $\left(\mathrm{CH}_{4}\right)$; nitrous oxide $\left(\mathrm{N}_{2} \mathrm{O}\right)$; hydrofluorocarbons (HFCs); perfluorocarbons (PFCs); sulfur hexafluoride $\left(\mathrm{SF}_{6}\right)$; and nitrogen trifluoride $\left(\mathrm{NF}_{3}\right)$. A coefficient called the global warming potential (GWP) was used to assess the impact of different gases on global warming. The GWP is calculated for a specified period (usually 20, 100 or 500 years) and depends on the absorption capacity of the light radiation and the life span of the gas in the atmosphere; in this way, a high GWP is correlated with a high heat absorption capacity and a longer gas life in the atmosphere.

$\mathrm{CO}_{2}$ was used as a reference for calculating the specific potential of each gas.

The predominance of carbon dioxide can be observed (Fig. 2). In the EU-28, approximately four-fifths of the total amount of gas was $\mathrm{CO}_{2}$, in comparison with Romania, which was two-thirds. We also noted that the carbon dioxide at the EU-28 level remained relatively constant at approximately $80 \%$, while in Romania, the trend decreased by approximately 10\% in 2017 compared to 1990. Another comparative aspect was represented by the relative constant weight of methane in the EU-28 of approximately $11 \%$. In Romania, the share of methane doubled, registering a growth trend from $26 \%$ in 1990 to approximately $29 \%$ in 2005 and reaching over $31 \%$ in 2017.
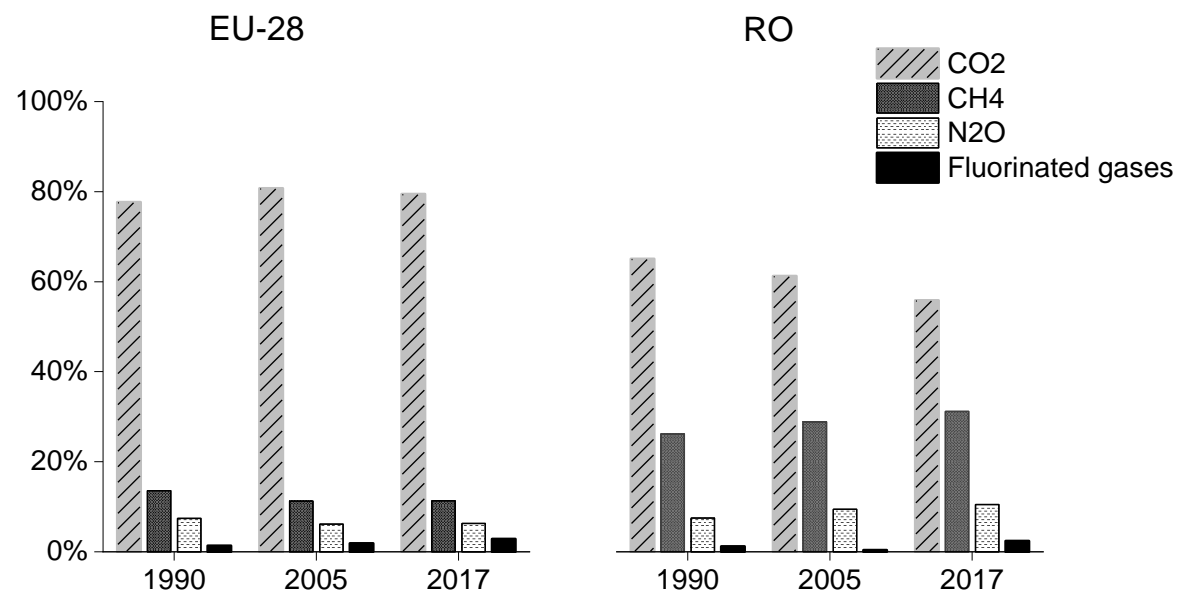

Figure 2. Dynamics of the GHG structure in the EU-28 and Romania 
An important aspect highlighted by our analysis was the increase after 2005 of the share of fluorinated greenhouse gases, namely, HFCs, PFCs, SF6, and NF3, which increased by 1.5 times in the EU-28 and more than 6.5 times in Romania. The heating potential of fluorinated gases after 100 years is higher than that of carbon dioxide (according to Forth Assessment Report - AR4) because they contain elements that have effects that are several hundred or thousands of times more powerful.

Compared to the reference year (1990), the leading greenhouse gases that cover more than $90 \%\left(\mathrm{CO}_{2}, \mathrm{CH}_{4}\right.$ and $\left.\mathrm{N}_{2} \mathrm{O}\right)$ of the total emissions registered decreasing trends both in the EU-28 and in Romania (Fig. 3). We noted that these tendencies were more pronounced in Romania, which explains the more obvious change in GHG structure than the structure in the EU-28. In terms of the dynamics of fluorinated gases, the trends were opposite between EU28 and Romania. Thus, in the EU-28, they showed a growth trend compared to 1990. In 2017, the level was approximately 116.5 million tons $\mathrm{CO}_{2}$-eq./year, and in 1990 , the level was 72 million tons $\mathrm{CO}_{2}$-eq./year. In Romania, the trend decreased until the middle of the last decade, after which it steadily increased but did not exceed the level from 1990. In 2017, the standard was approximately 2.24 million tons $\mathrm{CO}_{2}$-eq./year compared of in 1990 , when the emission quantity was 4.45 million tons $\mathrm{CO}_{2}$-eq./year.

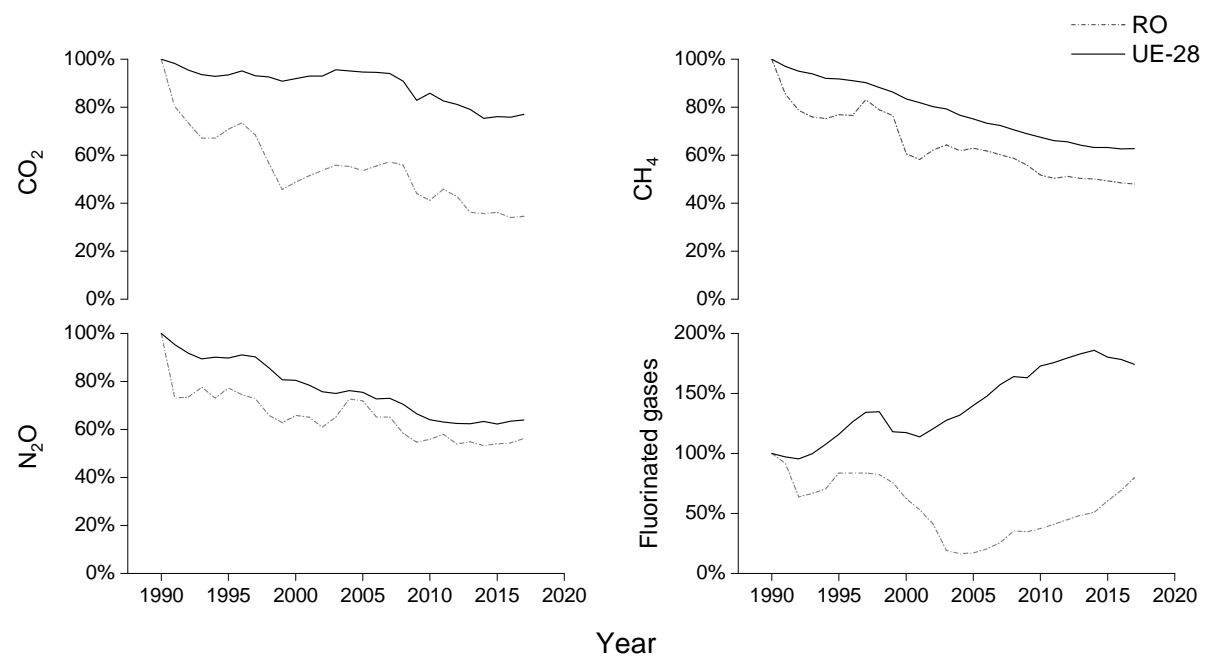

Figure 3. Trends in GHG emissions, EU-28 vs Romania

The evolution of $\mathrm{CO}_{2}$ showed a clear downward trend in Romania compared to the EU-28 average. Between 1990 and 2017, the emissions of carbon dioxide decreased at the European level by $1 \% / y e a r$ on average; in comparison, the emissions in Romania decreased by approximately $4.6 \%$ /year. The subperiod analysis shows that the evolution was more pronounced before 2005 when the average annual rate of decrease of $\mathrm{CO}_{2}$ emissions in Romania was approximately $5.3 \%$, almost 14 times higher than the average yearly rate of the EU-28 (-0.4\%/year). The dynamics of these emissions changed after 2005 in that the average yearly rate of decline slowed to 3.6\%/year. The EU-28 registered an average annual rate of decrease in emissions of $1.7 \%$ year (rate at an absolute value higher than the one recorded before 2005).

Methane, which is 24.5 times higher greenhouse gas than carbon dioxide (100 years), is the second largest contributor to climate change. The largest source of anthropogenic methane emissions is agriculture, especially animal husbandry. The second largest source 
comes from fossil fuel production, which allows underground methane to reach the atmosphere during drilling, extraction and transportation.

Between 1990 and 2017, the methane emissions decreased at an annual average rate of $1.7 \% / y e a r$ in the EU-28, while in Romania, the decrease rate was much more accentuated, at $3.3 \%$ /year. Before 2005, the average annual rate of decline was $4.14 \%$ year compared to that of the EU-28, which was 1.9\%/year. After 2005, the average yearly rates slowed down the slope compared to the previous period for Romania, when the average annual rate of decrease was half of that recorded before 2005 (2.2\% per year); in the EU-28, it was slightly lower at $1.5 \%$ /year. We noted that the rate of decrease in $\mathrm{CO}_{2}$ emissions $(-4.6 \%$ per year) was, in absolute value, higher than the rate of decrease of $\mathrm{CH}_{4}$ emissions ( $-3.3 \%$ per year), which explained the changes in the chemical structure of GHGs in Romania compared to EU-28.

The $\mathrm{N}_{2} \mathrm{O}$ (being 320 times higher potent greenhouse gas than $\mathrm{CO} 2-100$ years retention time) dynamics showed a clear downward trend, both in the EU-28 and Romania, as highlighted in Fig. 3. The largest source of $\mathrm{N} 2 \mathrm{O}$ emission is agriculture (cultures with fertilizers). The average annual rate of decrease was more pronounced in Romania $(-2.64 \%$ per year) compared to the average annual rate of decrease in the EU-28 (-1.64\%) over the analyzed time horizon. This was noted from the analysis by subperiods of time. Before 2005 , the average annual rate of decrease in $\mathrm{N}_{2} \mathrm{O}$ emissions was $3.1 \%$ per year for our country, given that at the European level, the average was $-1.86 \%$ per year. After 2005 , the average annual rates of decline were lower, in absolute value, than those that had been recorded previously (Romania, 2\%/year; EU-28, 1.37\%/year).

Fluorinated gases (being 8,500 times higher potent greenhouse gas than $\mathrm{CO} 2-\mathrm{HCFC}-$ FC substitute, 100 years - retention time) were the only GHG emissions that registered growth trends at the European level over the whole analyzed time horizon. In Romania, the emissions of fluorinated gases registered decreasing trends compared to the reference year, but the growth trend can be noticed, especially after joining the EU-28.

As observed in Fig. 3, the emission of fluorinated gases increased on average annually by $1.8 \%$ /year between 1990 and 2005 at the European level, while in Romania, they decreased by $\sim 11.1 \% / y e a r$. After 2005 , the situation at the European level remained the same as has been previously registered. Nevertheless, for Romania, the emissions of fluorinated gases substantially changed its tendency to decrease in the growth trend, registering an average annual growth of over $13 \%$ per year. The level of fluorinated gases modified the chemical composition of the GHG European network. Thus, the share of fluorinated gases increased by more than 6.5 times, from $0.37 \%$ in 2005 to over $2.4 \%$.

Furthermore, the effects of industries underpinning the technical progress, such as thinfilm solar cells (photovoltaic panels), flat screens, Li-ion battery construction, and mobile phone touch screens, fall under the recommendation about emerging EU measures for the progressive reduction of fluorinated greenhouse gases (Regulation 517, 2014), which indicated: "...developed countries would need to reduce greenhouse gas emissions by $80 \%$ to $95 \%$ below 1990 levels by 2050 to limit global climate change to a temperature increase of $2^{\circ} \mathrm{C}$ and thus prevent undesirable climate effects".

\section{Trend of GHG emissions by economic sector.}

For both the EU-28 and Romania, in this analysis, we considered GHG emissions without the absorption included in the LULUCF sector (Fig. 4). For both situations, a decreasing tendency was observed. The emissions level of Romania on the EU-28 scale decreased from $4.4 \%$ in 1990 to $2.7 \%$ in 2017. 

Bucura, Roxana Elena Ionete, Remus Grigorescu, Constantin Nechita

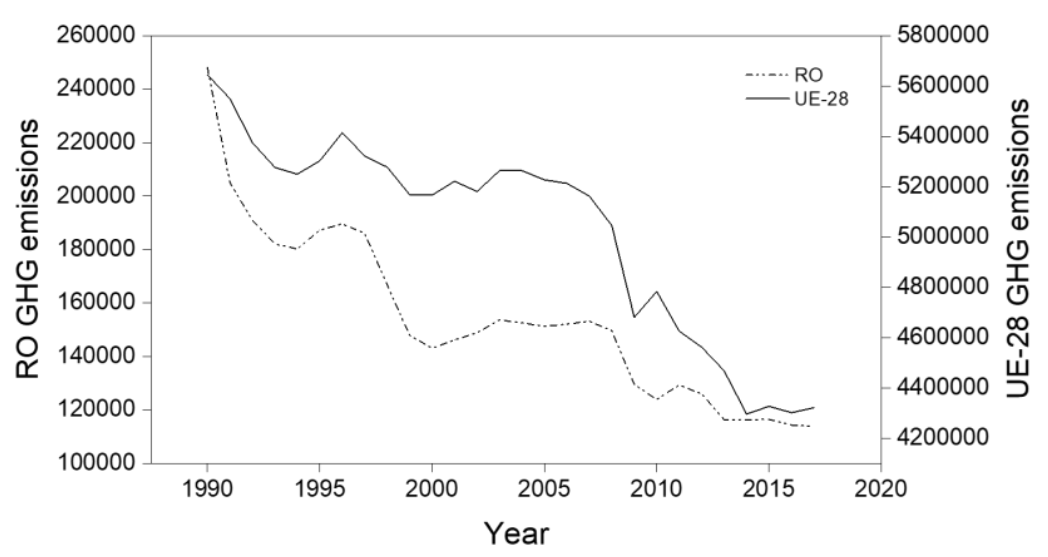

Figure 4. Trends in GHG emissions (without LULUCF absorption),

EU-28 vs Romania (thousands of tons $\mathrm{CO}_{2}$ equivalent)

The trends in GHG emissions emphasize the sharp decrease at the Romania level compared to that at the European Union. Throughout the analyzed period, the European level decreased on average annually by approximately $1 \%$ year. For Romania, the reduction rate was over three times higher. In absolute figures, the decrease in the analyzed time horizon was approximately 49.1 million tons $\mathrm{CO}_{2}$-eq./year at the European level and approximately 6.9 million tons $\mathrm{CO}_{2}$-eq./year in Romania (see Table 3). Even though Romania started in 2007, with a share of total GHG emissions in the European Union of approximately 3\% (see Fig. 4), the current contribution to the average annual decrease in emissions was $14 \%$ (Fig. 5).

Table 3. Modification of the absolute annual average of the sectoral GHG emissions from 1990-2017 and the sectoral contribution of Romania to the reduction of GHG emissions

\begin{tabular}{|c|c|c|c|}
\hline \multirow[b]{2}{*}{ Economic sector } & EU-28 & RO & \multirow{2}{*}{$\begin{array}{l}\text { The sectoral contribution of } \\
\text { Romania to reducing GHG } \\
\text { emissions at EU-28 level, \% }\end{array}$} \\
\hline & \multicolumn{2}{|c|}{ (thousands of tons of $\mathrm{CO}_{2}$ eq./ year) } & \\
\hline$\overline{\text { Energy }}$ & -36.327 & $\begin{array}{l}-5.102 \\
\end{array}$ & $14 \%$ \\
\hline Industrial processes & -5.174 & -1.104 & $22 \%$ \\
\hline Agriculture & -3.862 & -710 & $18.4 \%$ \\
\hline Emissions from LULUCF & -14 & +22 & - \\
\hline Waste & -3.761 & +27 & - \\
\hline Total & -49.139 & -6.867 & $14 \%$ \\
\hline
\end{tabular}

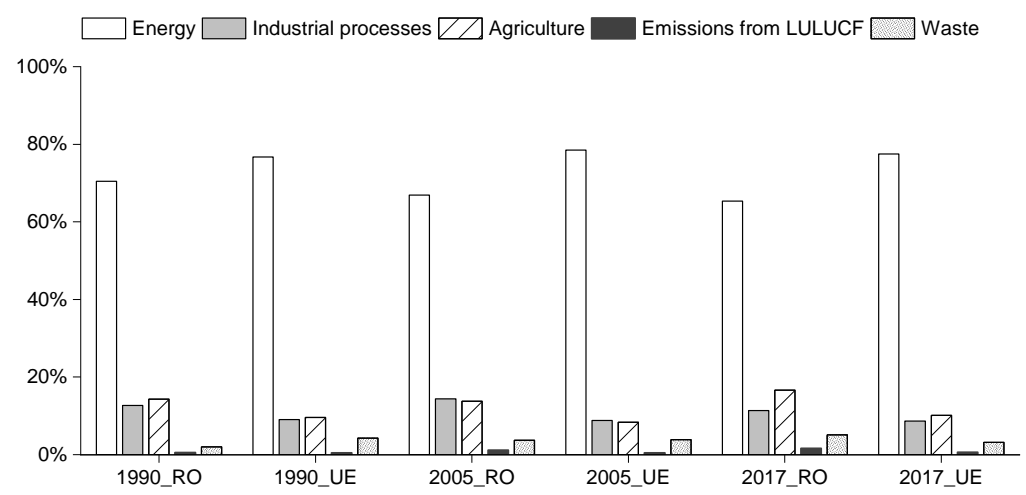

Figure 5. Structure by economic sectors of the GHG emissions at EU-28 level and Romania (source: graph built by authors based on information provided by the European Environment Agency) 
The energy sector occupied a relatively constant weight, at just over three-quarters of the total emissions in the EU-28 and only two-thirds in Romania. In the EU-28, the emissions from the energy sector decreased annually by approximately 36.3 million tons $\mathrm{CO}_{2}$-eq./year on average, representing approximately three-quarters of the average annual decrease recorded during the analyzed period (49.1 million tons $\mathrm{CO}_{2}$-eq./year).

Romania registered an average annual emissions reduction from the energy sector of 5.1 million tons $\mathrm{CO}_{2}$-eq./year. This measure contributed to the reduction of GHG emissions from the energy sector of more than 14\%, given that Romania's share of total amount of emissions from energy was relatively small; in 1990, the stock was $4 \%$, and in 2017 , it was $2.2 \%$ (Fig. 5).

The share of GHG emissions from industrial processes had a relatively constant trend in the EU-28, while in Romania the percentage was higher than that registered in the EU-28. In Romania, emissions from industrial processes had the following evolution: in 1990, this share was approximately $12.7 \%$; in 2005 , it increased slightly to $14.5 \%$; and in 2017 , it decreased to $11.3 \%$ (Fig. 5). In the EU-28, the emissions from industrial processes decreased annually at a rate of approximately 5.2 million tons $\mathrm{CO}_{2}$-eq./year on average, and in Romania, they decreased by 1.1 million tons $\mathrm{CO}_{2}$-eq./year. Just over one-fifth of reduction in emissions from industrial processes in the EU-28 was from Romania (Table 3).

The GHG emissions in the agricultural sector from EU-28 were stable over time (810\%). Romania, on the contrary, showed a change of 14\% between 1990 and 2005; in 2017, this level increased to approximately $16.7 \%$ at present (Fig. 5). In Romania, the emissions decreased annually by approximately 0.7 million tons $\mathrm{CO}_{2}$-eq./year on average in the analyzed period, representing $18 \%$ of the total annual decrease recorded in the EU-28 (Table 3).

The share of emissions from the LULUCF sector in the EU-28 was relatively constant at approximately $0.5 \%$; in Romania, this share increased by three times in 2017 compared to the reference year (from $0.5 \%$ in the reference year to $1.6 \%$ in 2017) (Fig. 5). If, at the European level, the emissions from LULUCF decreased annually by approximately 14 thousand tons of $\mathrm{CO}_{2}$-eq./year on average, in Romania, they increased annually by 22 thousand tons of $\mathrm{CO}_{2}$-eq./year on average.

The GHG emissions from waste decreased in the EU-28 from $4.2 \%$ in 1990 to $3.7 \%$ in 2005 and $3.2 \%$ in 2017 . The emissions from waste decreased annually by approximately 3.8 million tons of $\mathrm{CO}_{2}$-eq./year on average at the European level. In Romania, waste GHG emissions increased from $2 \%$ in 1990 to $3.7 \%$ in 2005, reaching over 5\% in 2017 (Fig. 5). In almost 30 years, this figure has doubled, so the GHG emissions from waste have increased every year by approximately 27 thousand tons of $\mathrm{CO}_{2}$-eq./year on average.

\section{DISCUSSION}

The global atmospheric concentrations of GHG emissions in 2018 reached $407.8 \pm 0.1$ ppm for $\mathrm{CO}_{2}$, which was $147 \%$ higher than preindustrial levels. Furthermore, the measurements from individual sites indicated that the concentrations of $\mathrm{CO}_{2}$ continued to increase in 2019, and even $\mathrm{CH}_{4}$ and $\mathrm{N}_{2} \mathrm{O}$ also reached record levels. The global mean temperature from January to October 2019 was $1.1 \pm 0.1{ }^{\circ} \mathrm{C}$ above preindustrial levels. The past five years were the warmest years recorded since the beginning of instrumental measurements, and the past decade (2010-2019) represents the warmest decade on record. Since the 1980s, each successive decade has been warmer than any preceding decade since 1850 (Li et al., 2018; WMO, 2019).

The climate changes have been ascribed to a limited extent to human emissions of GHG that began once with the period of industrial revolution. Concentration levels of $\mathrm{CO}_{2}$ in air have grown by over $30 \%$ (between 280 and 380 ppm), while $\mathrm{N}_{2} \mathrm{O}$ and $\mathrm{CH}_{4}$ have expanded by $17 \%$ 
and $151 \%$, respectively. The composition of the atmosphere alters the Earth's radiative balance greenhouse gases reduce heat emissions from the Earth's atmosphere into space, trapping more heat into the atmosphere and thus raising global temperatures. Solar variability is an essential factor of climate in the radiative evolution of the Earth over time, in terms of changes observed in the global climate (Preston and Jones, 2006).

The global atmospheric concentrations of greenhouse gases (mainly $\mathrm{CO}_{2}, \mathrm{CH}_{4}$, and $\mathrm{N}_{2} \mathrm{O}$ ) have increased significantly since 1750 . The eleven years from 1995-2006 were among the hottest years recorded since the beginning of global temperature instrument registration. The linear heating trend for the last 50 years $\left(0.13^{\circ} \mathrm{C}\left[0.10\right.\right.$ to $\left.0.16^{\circ} \mathrm{C}\right]$ per decade) is almost double that of the last 100 years. The total temperature increase from 1850-1899 that occurred from $2001-2005$ was $0.76^{\circ} \mathrm{C}$ [ 0.57 to $\left.0.95^{\circ} \mathrm{C}\right]$. The climatic records for Romania showed an increase that was similar or even slightly more pronounced. The average annual temperature increased over the last 33 years by $0.5^{\circ} \mathrm{C}\left(1981-2013 / 10.2^{\circ} \mathrm{C}\right)$, or $0.16^{\circ} \mathrm{C}$ per decade (Diniz Oliveira et al., 2019). The warmest year in the history of meteorological records in the country was 2007. Although it has not been directly attributed to climate change, the intensification of extreme events has also been noticeable. In 2005, Romania recorded disastrous floods that led to 76 deaths and significant material damage, and 2007 and 2012 were the most drought-stricken years, with severe effects on agriculture. From 1901 until now, there have been 3 or 4 years of extreme drought or extreme rainfall in each decade, with the highest number of drought years (five) being recorded in the decade from 2001-2010 (Romanian National Strategy on Climate Change, 2016-2020).

Although Romania's contribution to global emissions is insignificant (only $0.3 \%$ of the world's greenhouse gas emissions and less than 3\% of total EU countries' emissions), Romania was the first country in Annex 1 to ratify the Kyoto Protocol (KP). By 2020, Romania has to meet the "20-20-20" targets within the EU "Energy and Climate Package" (Annex III), which stipulates a 20\% reduction in greenhouse gas emissions compared to 1990 levels, an increase in the share of energy consumption from renewable sources by $20 \%$ and a $20 \%$ improvement in energy efficiency. This strategy goes beyond the 2020 objectives regarding the short-term targets that Romania is very close to achieving. The climate change strategy focuses on reaching the goals of the 2030 energy and climate package. It builds a path towards a low carbon economy for Romania as presented in the Europe 2050 Roadmap $(\operatorname{COM}(2011) 112,2011)$.

The energy sector is the most significant source of $\mathrm{CO}_{2}$ emissions due to fossil fuels which have been very well analyzed using consolidated international energy statistics. Land use change is the second most significant anthropogenic source of $\mathrm{CO}_{2}$, these data are difficult to estimate due to the lack of general statistical information, even if it is necessary to assess the disturbances caused by human activities in the carbon cycle and the natural carbon cycle. (De Campos et al., 2005).

The reduction of GHG emissions is one of the actions that has been prompted by climate change, and it is seen as leading to new economic activities with long-term impacts. Thus, adaptation plans spanning over 50 years are beginning to be seen as customary and are at the lower limit of the time constants regarding the paradigm shift of energy systems, as well as climate change. The United Nations Framework Convention on Climate Change (UNFCCC, 1992), which was adopted at the summit held in Rio de Janeiro in 1992 ("The Earth Summit"), is a fundamental tool for managing this challenge. Additionally, the Kyoto Protocol (KP), which was adopted on December 11, 1997, and ratified on February 16, 2005, significantly strengthens the Convention by committing Annex I parties to individual legally binding targets for reducing or limiting their greenhouse gas emissions from 2008-2012.

Romania ratified the UNFCCC (Law 24, 1994) and the Kyoto Protocol to the UNFCCC (Law 3, 2001). More than 180 parties of the United Nations Framework 
Convention on Climate Change (UNFCCC) met in Paris from November 30 to December 12,2015 , to negotiate a new global and legally binding deal for addressing climate change mitigation in the $21^{\text {st }}$ Conference of the Parties (COP-21) (UNFCCC, 2015). The Paris Agreement (Law 57, 2016), which was within the UNFCCC, came into effect on November 4, 2016 and brought for the first time all nations into a common cause: undertaking ambitious efforts to combat climate change and adapt to its effects. It became effective by 2020 , when approximately 105 parties, accounting for more than 55\% of the total global greenhouse gas emissions, have deposited their instruments to ratify the agreement (Ellison et al., 2014; Cellura et al., 2018; Diniz Oliveira et al., 2019; Arioli et al., 2020).

\section{Climate change mitigation policies.}

The European energy policies will lead to a safer and more sustainable economy with low energy consumption. The priorities in the field of energy are: the competitive functioning of the internal energy market and the reduction of GHG emissions caused by energy consumption. The EU's dependence on gas and oil imports, as well as the adverse effects of fossil fuel use on the climate, are the energy challenges facing Europe.

One solution to reduce the EU's dependence on imported gas could be to identify alternatives to fossil fuels (nuclear, wind, solar, thermal, hydroelectric and geothermal).

The EU adopted a strategy to diversify the fuel supply sources to meet its energy needs. The development of biofuels and biomass could contribute to this goal. The European Commission has proposed a mandatory target to be achieved by 2020 , namely, that $20 \%$ of all energy produced in Europe comes from renewable sources (wind, sun, waves, as well as bioenergy sources). Currently, only $6.7 \%$ of the total energy consumption in Europe comes from renewable sources. Two-thirds of this percentage comes from biomass. In 2006, a study conducted by the European Environment Agency (EEA) considered that $15 \%$ of the European energy demand estimated for 2030 could be covered by bioenergy obtained from agricultural, forestry and waste products, which should involve only European resources. According to Regulation (EC) no. 1782/2003, art. 88, energy crops are used in the manufacture of biofuels, such as biodiesel, bioethanol or for the energy value obtained by combustion, for the generation of heat or electricity. To further the definition, it is noted that these must be plant crops established with minimal costs and a low harvesting costs (EC Regulation 1782, 2003; Streimikiene and Balezentis, 2016).

To support green economic growth to reduce carbon content, the EU introduced ambitious climate and energy targets for 2020 and was the first region to pass binding legislation. Romania's obligations as an EU member state include participation in the EU limitation and marketing mechanism in the GHG emissions certification scheme (ETS) for all large energy-consuming installations. The smaller units and operators in the lower energy sectors the aim to reduce greenhouse gas emissions by $19 \%$ in 2020 compared to the level in 2005. Romania had been committed to increasing the share of energy from renewable sources in energy consumption from $18 \%$ in 2005 to $24 \%$ by 2020 , since the country's policy on fighting climate change had been aimed at both reducing GHGs and adapting to the effects of climate change. The Guide on Adaptation to Climate Change Effects (GACC) from 2008 and Romania's national strategy on climate change from 2016-2020, which was implemented in 2016, are the main actions to reduce greenhouse gas emissions and increase the removal capacity of $\mathrm{CO}_{2}$ from the atmosphere and had also measures to adapt to the effects of climate change.

Romania efforts to fight climate change are focused on creating a climate-resilient economy with low carbon dioxide emissions, which has integrated its policies and actions related to climate change into smart economic growth, which aims to be "green" and inclusive by 2030. Several tasks were included as follows: 
1) Establishing and reaching national targets for climate change and energy in line with European climate change policy by reaching $(i)$ a $20 \%$ reduction in greenhouse gas emissions compared to 1990 levels, increasing the share of energy consumption from renewable sources by $20 \%$, and improving energy efficiency by $20 \%$ by 2020 ; (ii) intensifying efforts to transition to a "green" economy with low carbon dioxide emissions and resilience to climate change, especially in terms of improving energy efficiency and renewable energy implementation, such as by integrating measures to adapt to climate change within the sectors concerned by 2030; and (iii) transitioning to a climate-resilient economy and a greener economy, in which social, economic and environmental policies and actions will be interconnected and designed to ensure sustainable development, with high standards of living for all citizens as well as high environmental quality by 2050 .

2) Adopting the cross-sectoral and integrated approach: climate change must be managed in all sectoral programs, especially those related to energy, transport, urban development, water resources, forestry, agriculture and rural development. In addition to the cross-sectoral approach, integration would also require addressing different dimensions: reducing GHG emissions, adapting climate change, and increasing institutional availability and the availability of appropriate financing instruments as well as the participation and inclusion of multiple stakeholders.

3) Maximizing the economic and social benefits of the climate change measures: many measures to adapt to climate change and reduce them, as well as measures, should be taken to improve water management or increase energy efficiency. Additionally, investments should be beneficial for all parties involved, which can help to avoid high costs in the event of extreme meteorological events. Furthermore, innovative solutions that would be justified in terms of contributing to solving current problems are to be promoted.

\section{CONCLUSIONS}

GHG emission trend in the EU-28 and Romania has been analyzed. For that, the method of modifying the absolute mean was applied to reveal the significance, direction, rate, and drivers of the observed evolution of total GHG emissions of the six sectors of the 28 EU countries, over almost three decades. Was revealed that, in general, the EU's performance improved during the study period (1990-2017), showing a decrease in average emissions intensity, an increase in the rate of carbon removal, and by increasing number of country showing net decreases in GHG emissions year-on-year. The decrease in GHG emissions can be explained by the decrease in industrial production, but mainly by the measures implemented during the pre - and post - accession to the EU.

The study emphasizes that in the EU-28, the GHG emissions decreased annually by $1 \%$ on average, with $25 \%$ lower emissions in 2017 in comparison to 1990 and approximately $17 \%$ lower emissions reported in 2005. In fact, GHG emissions decreased between 1990 and 2005 by 32.3 million tons $\mathrm{CO}_{2}$-eq./year compared to the preceding period (2005-2017), when the value was almost doubled, with an increase of 57 million tons $\mathrm{CO}_{2}$-eq./year. The analyzed data showed that Germany, Great Britain, France, and Italy produced more than half GHG emissions in the European Union, meaning that these countries produced $57 \%$ in 1990 , over $55 \%$ in 2005, and approximately $54 \%$ in 2017 . Romania contributed only $0.3 \%$ of the world's greenhouse gas emissions and less than 3\% of the total of EU-28 countries to global emissions; in addition, it was the first country in Annex 1 to ratify the Kyoto Protocol. The Romanian share of the total EU-28 GHG emissions was $4.2 \%$ and decreased in 2005 to $2.7 \%$ and $2.3 \%$ in 2017 .

The EU-28 $\mathrm{CO}_{2}$ emissions level remained relatively constant over time (80\%) while in Romania, the trend decreased by $10 \%$ from 1990 to 2017 . The relative constant weight 
of methane emissions in the EU-28 $(\sim 11 \%)$ was reported in contrast to Romania, where the share of methane doubled, with an increasing trend from $26 \%$ (1990) to $29 \%$ (2005) to over $31 \%$ (2017). The alarming increase in methane emissions could prevent the $2{ }^{\circ} \mathrm{C}$ warming target from reaching pre-industrial levels set in the Paris Agreement. That is why urgent measures are needed to reduce these emissions, which will amplify global warming.

HFCs, PFCs, SF6 and NF3 have significant heating potential that is higher than that of $\mathrm{CO}_{2}$. The share of these compounds in the total GHG emissions increased by 1.5 times in the EU-28 and more than 6.5 times in Romania after 2005. This worrying situation is the effect of some industries that are the basis of technical progress: thin-film solar cells (photovoltaic panels), flat screens, the construction of Li-ion batteries, touch screens of mobile phones, etc.

Considering the reference year 1990, the leading greenhouse gases that covered more than $90 \%\left(\mathrm{CO}_{2}, \mathrm{CH}_{4}\right.$ and $\left.\mathrm{N}_{2} \mathrm{O}\right)$ of the total $\mathrm{GHG}$ emissions registered decreasing trends in both the EU-28 and Romania. We noted that these tendencies were more pronounced in Romania, which contributed to a decrease in emissions starting from $3 \%$ in 2007 and reaching $14 \%$ to date, which explains the more obvious change in GHG structure compared with EU-28.

Considering that each sector that contributed to GHG emissions in Romania, over 5.1 million tons $\mathrm{CO}_{2}$-eq./year were removed from the energy sector. Industrial processes have had a relatively constant trend in the EU-28, and in Romania, the percentage increased after 2007. The agricultural sector was stable in the EU-28 (8-10\%). In contrast, the industrial processes in Romania demonstrated an increase from 14\% (1990 - 2005) to 16.7\% (2005-2017). Even the share of emissions from the LULUCF sector in the EU-28 was relatively constant at approximately $0.5 \%$ but tripled in Romania, reaching a level of $1.6 \%$ in 2017. The GHG waste emissions decreased by 3.8 million tons of $\mathrm{CO}_{2}$-eq./year at EU-28 and increased substantially in Romania, by 2\% (1990) to 3.7\% (2005), and 5\% (2017), respectively. An explanation comes from the fact that Romania currently has several non-compliant landfills and also does not have an integrated process of selective waste collection yet.

According to our findings, we suggest future strategies for integrating policy to overcome the economic, social and environmental dimensions of reducing GHG emissions in Romania using a technical perspective.

Acknowledgements: The work was supported by the Romanian Ministry of Research and Innovation - grants number: PN19070502 "Transdisciplinary assessment of decline oak trees in the extra-Carpathian area, affected by the current environmental changes - adaptation, mitigation and risk" and PN 19110303 "Advanced techniques for identifying sources of contamination and biochemical reactions in aquatic ecosystems".

Funding: Project PN 19110303, Contract no. 9N/2019, financed by the Ministry of Education and Research, Romania.

Author contributions: M.I., R.Z. wrote the original draft, and all authors contributed to the analysis and article review. Figures were created by R.E.I., R.G. and C.N. coordinated the analysis for this paper. The policy inventory and database were created by M.C and F.B. The scenario database was coordinated by M.I., R.Z. and A.M.I. All authors have formulated the conclusions.

Conflict of Interest Statement: The authors declare no conflicts of interest associated with this manuscript. 
Mihaela Iordache, Ramona Zgavarogea, Andreea Maria Iordache, Marius Constantinescu, Felicia Bucura, Roxana Elena Ionete, Remus Grigorescu, Constantin Nechita

\section{REFERENCES}

Allen, M.R., O.P. Dube, W. Solecki, F. Aragón-Durand, W. Cramer, S. Humphreys, M. Kainuma, J. Kala, N. Mahowald, Y. Mulugetta, R. Perez, M. Wairiu, and K. Zickfeld, 2018. Framing and Context. In: Global Warming of $1.5^{\circ} \mathrm{C}$. An IPCC Special Report on the impacts of global warming of $1.5^{\circ} \mathrm{C}$ above preindustrial levels and related global greenhouse gas emission pathways, in the context of strengthening the global response to the threat of climate change, sustainable development, and efforts to eradicate poverty [Masson-Delmotte, V., P. Zhai, H.-O. Pörtner, D. Roberts, J. Skea, P.R. Shukla, A. Pirani, W. Moufouma-Okia, C. Péan, R. Pidcock, S. Connors, J.B.R. Matthews, Y. Chen, X. Zhou, M.I. Gomis, E. Lonnoy, T. Maycock, M. Tignor, and T. Waterfield (eds.)], In Press.

Arioli, M.S., D'Agosto, M. de A., Amaral, F.G., Cybis, H.B.B., 2020. The evolution of city-scale GHG emissions inventory methods: A systematic review. Environ. Impact Assess. Rev. https://doi.org/10.1016/j.eiar.2019.106316.

Cellura, M., Cusenza, M.A., Longo, S., 2018. Energy-related GHG emissions balances: IPCC versus LCA. Sci. Total Environ. 628-629, 1328-1339. https://doi.org/10.1016/j.scitotenv.2018.02.145.

Council Regulation (EC) No 1782/2003 of September 292003 establishing common rules for direct support schemes under the common agricultural policy and establishing certain support schemes for farmers and amending Regulations (EEC) No 2019/93, (EC) No 1452/2001, (EC) No 1453/2001, (EC) No 1454/2001, (EC) 1868/94, (EC) No 1251/1999, (EC) No 1254/1999, (EC) No 1673/2000, (EEC) No 2358/71 and (EC) No 2529/2001.

EC, $\operatorname{COM}(2011) 112$ - A Roadmap for moving to a competitive low carbon economy in 2050 - European Environment Agency, 2011. https://www.eea.europa.eu/policy-documents/com-2011-112-a-roadmap (accessed February 262020 ).

Crippa, M., Oreggioni, G., D, G., Muntean, M., Schaaf, E., Lo Vullo, E., Solazzo, E., Monforti-Ferrario, F., Olivier, J.G.., Vignati, E., 2019. Fossil $\mathrm{CO}_{2}$ and GHG emissions of all world countries - 2019 Report, EUR 29849 EN. Publications Office of the European Union. https://doi.org/10.2760/687800.

De Campos, C.P., Muylaert, M.S., Rosa, L.P., 2005. Historical CO2 emission and concentrations due to land use change of croplands and pastures by country. Sci. Total Environ. 346, 149-155. https://doi.org/10.1016/j.scitotenv.2004.12.053.

Diniz Oliveira, T., Costa Gurgel, A., Tonry, S., 2019. International market mechanisms under the Paris Agreement: A cooperation between Brazil and Europe. Energy Policy 129, 397-409. https://doi.org/10.1016/j.enpol.2019.01.056.

Ellison, D., Lundblad, M., Petersson, H., 2014. Reforming the EU approach to LULUCF and the climate policy framework. Environ. Sci. Policy 40, 1-15. https://doi.org/10.1016/j.envsci.2014.03.004.

Hachem, C., 2016. Impact of neighborhood design on energy performance and GHG emissions. Appl. Energy 177, 422-434. https://doi.org/10.1016/j.apenergy.2016.05.117.

Harris, S., Weinzettel, J., Bigano, A., Källmén, A., 2020. Low carbon cities in 2050? GHG emissions of European cities using production-based and consumption-based emission accounting methods. J. Clean. Prod. 248, 119206. https://doi.org/10.1016/j.jclepro.2019.119206.

Krausmann, F., Wiedenhofer, D., Haberl, H., 2020. Growing stocks of buildings, infrastructures and machinery as key challenge for compliance with climate targets. Glob. Environ. Chang. 61, 102034. https://doi.org/10.1016/j.gloenvcha.2020.102034.

Law no. 3/2001 for the ratification of the Kyoto Protocol to the United Nations Framework Convention on Climate Change, adopted on December 11, 1997.

Law no. 24/1994 for the ratification of the United Nations Framework Convention on Climate Change, signed in Rio de Janeiro on June 5, 1992.

LAW no.57 of April 10, 2017 for the ratification of the Paris Agreement, concluded in Paris on December 12, 2015 and signed by Romania in New York on April 22, 2016.

Leung, D.Y.C., Caramanna, G., Maroto-Valer, M.M., 2014. An overview of current status of carbon dioxide capture and storage technologies. Renew. Sustain. Energy Rev. https://doi.org/10.1016/j.rser.2014.07.093.

Li, Z., Wang, D., Sui, P., Long, P., Yan, L., Wang, X., Yan, P., Shen, Y., Dai, H., Yang, X., Cui, J., Chen, Y., 2018. Effects of different agricultural organic wastes on soil GHG emissions: During a 4-year field measurement in the North China Plain. Waste Manag. 81, 202-210. https://doi.org/10.1016/j. wasman.2018.10.008.

Olivier, J. G., Schure, K. M., \& Peters, J. A. H. W. (2017). Trends in global CO2 and total greenhouse gas emissions. PBL Netherlands Environmental Assessment Agency, 5. 
Oka, K., Mizutani, W., \& Ashina, S. (2020). Climate change impacts on potential solar energy production: A study case in Fukushima, Japan. Renewable Energy, 153, 249-260.

Preston, B.L., Jones, R.N., 2006. Climate Change Impacts on Australia and the Benefits of Early Action to Reduce Global Greenhouse Gas Emissions.

Ramachandra, T. V., Bharath, H.A., Kulkarni, G., Han, S.S., 2018. Municipal solid waste: Generation, composition and GHG emissions in Bangalore, India. Renew. Sustain. Energy Rev. https://doi.org/10.1016/j.rser.2017.09.085.

Rive, N., Fuglestvedt, J.S., 2008. Introducing population-adjusted historical contributions to global warming. Glob. Environ. Chang. 18, 142-152. https://doi.org/10.1016/j.gloenvcha.2007.09.004

Romania - 2016-2020 National action plan on climate change.

Sferra, F., Krapp, M., Roming, N., Schaeffer, M., Malik, A., Hare, B., \& Brecha, R. (2019). Towards optimal $1.5^{\circ}$ and $2^{\circ} \mathrm{C}$ emission pathways for individual countries: A Finland case study. Energy Policy, 133, 110705.

Shen, L., Sun, Y., 2016. Review on carbon emissions, energy consumption and low-carbon economy in China from a perspective of global climate change. J. Geogr. Sci. 26, 855-870. https://doi.org/10.1007/s11442-016-1302-3.

Song, J., Yang, W., Wang, S., Wang, X., Higano, Y., Fang, K., 2018. Exploring potential pathways towards fossil energy-related GHG emission peak prior to 2030 for China: An integrated input-output simulation model. J. Clean. Prod. 178, 688-702. https://doi.org/10.1016/j.jclepro.2018.01.062.

Štreimikiene, D., Balezentis, T., 2016. Kaya identity for analysis of the main drivers of GHG emissions and feasibility to implement EU "20-20-20" targets in the Baltic States. Renew. Sustain. Energy Rev. https://doi.org/10.1016/j.rser.2015.12.311.

Su, M., Pauleit, S., Yin, X., Zheng, Y., Chen, S., Xu, C., 2016. Greenhouse gas emission accounting for EU member states from 1991 to 2012. Appl. Energy 184, 759-768. https://doi.org/10.1016/j. apenergy.2016.02.074.

Torres, M., Pinho, P., 2011. Encouraging low carbon policies through a Local Emissions Trading Scheme (LETS). Cities 28, 576-582. https://doi.org/10.1016/j.cities.2011.06.005.

UNFCCC (1992). "United Nations Framework Convention on Climate Change Article 4, Para 1(a)." IPCC (1995a). Climate Change 1995: The Science of Climate Change - Contribution of Working Group I to the Second Assessment of the Intergovernmental Panel on Climate Change (IPCC). Cambridge, UK, Cambridge University Press.

UNFCCC, 2015. Historic Paris Agreement on Climate Change 195 Nations Set Path to Keep Temperature Rise Well Below 2 Degrees Celsius.

Vares, S., Häkkinen, T., Ketomäki, J., Shemeikka, J., Jung, N., 2019. Impact of renewable energy technologies on the embodied and operational GHG emissions of a nearly zero energy building. J. Build. Eng. 22, 439-450. https://doi.org/10.1016/j.jobe.2018.12.017.

WMO Provisional Statement on the State of the Global Climate in 2019 | World Meteorological Organization [WWW Document], n.d. URL https://public.wmo.int/en/resources/library/wmoprovisional-statement-state-of-global-climate-2019 (accessed February 19 2020).

Zheng, X., Streimikiene, D., Balezentis, T., Mardani, A., Cavallaro, F., Liao, H., 2019. A review of greenhouse gas emission profiles, dynamics, and climate change mitigation efforts across the key climate change players. J. Clean. Prod. https://doi.org/10.1016/j.jclepro.2019.06.140.

World Meteorological Organization, 2016. WMO Greenhouse gas Bulletin - The state of Greenhouse gases in the atmosphere based on global observations through 2016, https://ane4bf-datap1.s3-eu-west1.amazonaws.com/wmocms/s3fs-public/ckeditor/files/GHG_Bulletin_13_EN_final_1_1.pdf?LGJN mHpwKkEG2Qw4mEQjdm6bWxgWAJHa (accessed in March 312020$)$.

This article is an open access article distributed under the terms and conditions of the Creative Commons Attribution (CC BY-NC-ND 4.0) license (https://creativecommons.org/licenses/by-nc-nd/4.0/). 